Department of

Economics and Finance

高 $\quad$ E Philip Davis and Dilruba Karim

a

Macroprudential Regulation: The Missing Policy Pillar

J une 2009 


\title{
MACROPRUDENTIAL REGULATION - THE MISSING POLICY PILLAR
}

\author{
E Philip Davis and Dilruba Karim 1 \\ Brunel University and NIESR \\ London
}

Keynote address at the $6^{\text {th }}$ Euroframe Conference on Economic Policy Issues in the European Union, $12^{\text {th }}$ June 2009, entitled "Causes and consequences of the current financial crisis, what lessons for EU countries?”

\footnotetext{
${ }^{1}$ Davis is Professor of Economics and Finance and Karim is a Doctoral Research Student, Department of Economics and Finance, School of Social Sciences, Brunel University, Uxbridge, Middlesex, UB8 3PH, UK, emails e_philip_davis@msn.com and dilly.karim@gmail.com. Davis is also Visiting Fellow, NIESR, Dean Trench Street, Smith Square, London SW1. This paper is an updated version of Davis and Karim (2008c) which also appeared in Mayes and Pringle (2009).
} 
Macroprudential can be defined as policy that focuses on the financial system as a whole, and also treats aggregate risk as endogenous with regard to collective behaviour of institutions. It aims to limit system wide distress so as to avoid output costs associated with financial instability (Borio 2009). This article seeks to assess the need for a macroprudential policy pillar and the degree to which progress has been made in instituting one, viewed in the light of lessons learnt in the field of financial stability over the past decade. During this period there have been numerous crises, coinciding with considerable research and developments in policy and culminating in the lessons of the current crisis. A major impetus to these have been a growing realisation of the costs of crises, which can exceed 20\% of GDP (Hoggarth and Sapporta 2001), and the link of such crises to shared exposure to macroeconomic risks and not simply the failure of a single large institution. Many central banks have obtained a mandate to pursue financial stability (Das et al 2004). A key policy development has been Macroprudential Surveillance, although as highlighted, there remain some unanswered questions as to its use in practice in full-blown Macroprudential Regulation.

\section{Why we need macroprudential regulation - developments in the understanding of the process of financial instability}

\section{(a) A generic approach}

A primary issue, and background for the rest of the article, is a growing realisation of the generic nature of financial crises. In other words, they are not random events but share key common features.

\begin{tabular}{|l|l|l|}
\hline Phase of crisis & Nature & Example of features \\
\hline $\begin{array}{l}\text { Primary } \\
\text { (favourable) shock }\end{array}$ & Diverse & $\begin{array}{l}\text { Deregulation, monetary or fiscal easing, invention, } \\
\text { change in market sentiment }\end{array}$ \\
\hline $\begin{array}{l}\text { Propagation - } \\
\text { build-up of } \\
\text { vulnerability }\end{array}$ & $\begin{array}{l}\text { Common - main } \\
\text { subject of } \\
\text { macroprudential } \\
\text { surveillance }\end{array}$ & $\begin{array}{l}\text { New entry to financial markets, Debt accumulation, } \\
\text { Asset price booms, Innovation in financial markets, } \\
\text { Underpricing of risk, risk concentration and lower } \\
\text { capital adequacy for banks, Unsustainable macro } \\
\text { policy }\end{array}$ \\
\hline $\begin{array}{l}\text { Secondary } \\
\text { (adverse) shock }\end{array}$ & Diverse \\
\hline $\begin{array}{l}\text { Propagation - } \\
\text { crisis }\end{array}$ & Common & $\begin{array}{l}\text { Failure of institution or market leading to failure of } \\
\text { others via direct links or uncertainty in presence of } \\
\text { asymmetric information - or generalised failure due } \\
\text { to common shock }\end{array}$ \\
\hline Policy action & $\begin{array}{l}\text { Common - main } \\
\text { subject of crisis } \\
\text { resolution }\end{array}$ & $\begin{array}{l}\text { Deposit insurance, lender of last resort, general } \\
\text { monetary easing }\end{array}$ \\
\hline $\begin{array}{l}\text { Economic } \\
\text { consequences }\end{array}$ & $\begin{array}{l}\text { Common - scope } \\
\text { depends on } \\
\text { severity and } \\
\text { policy action }\end{array}$ & $\begin{array}{l}\text { Credit rationing and wider uncertainty leading to fall } \\
\text { in GDP, notably investment }\end{array}$ \\
\hline
\end{tabular}

As highlighted in Table 1, there are both exogenous and endogenous aspects. The process often starts with a primary shock to the economy and financial system that is favourable to growth and investment. But this leads to a process of propagation, whereby there is a build-up of vulnerability in the economy and financial system, associated with overextension of 
balance sheets and build up of financial imbalances. Price based measures of asset values rise and price based measures of risk fall. Moreover, these changes may not be in line with fundamentals, leading to mispricing. Balance sheets grow, short term funding increases and leverage falls. These exacerbate the boom and leading to a crisis when a secondary (adverse) shock hits a vulnerable financial system. In turn, there is further propagation in a crisis period (systemic risk) that typically entails policy reactions if the crisis is sufficiently severe, and considerable adverse economic consequences (the "costs of instability”). (b) Types of crisis

In the past decade, awareness has grown that while traditional banking crises remain a major manifestation of financial instability, especially in emerging market economies, there are alternative forms of crisis that may equally lead to systemic consequences. These are related to the ongoing securitisation of financial systems. One is extreme market price volatility after a shift in expectations (see Davis 2002). Whereas violent price movements may in themselves not have systemic implications ${ }^{2}$, these may emerge when such movements threaten institutions that have taken leveraged positions on the current levels of asset prices. Currency crises, a subset of these, may sharply affect banking systems, giving rise to "twin crises" (Kaminsky and Reinhart 1999) as in Asia in 1997 and Argentina in 2001.

There may instead be protracted ${ }^{3}$ collapses of debt or derivatives market liquidity and issuance (see Davis 1994). The risks are acute not only for those holding positions in the market but also for those relying on the market for debt finance or liquidity - which increasingly include banks. The Russia/LTCM crisis of 1998 and, particularly, the US SubPrime crisis of 2007-8 showed that these market-liquidity crises are recurrent features of modern financial systems, and given the structure of the modern financial system they can rapidly shift across borders. The Sub-Prime crisis has shown that interbank market liquidity can be highly vulnerable as well as that of securitised debt markets. Periodic collapse has been a feature of international interbank markets (Bernard and Bisignano 2000) but had hitherto been less common in domestic interbank markets.

\section{(c) Lessons from traditional theory}

The traditional theories of financial instability are set out in Davis (1995, 1999, 2002). Rather than repeating them here, we highlight some aspects shown to be of particular relevance in the past decade. The "financial fragility" view 4 (Kindleberger (1978), Minsky (1977)); has been repeatedly vindicated by recurrence of credit and asset price booms, followed by crises, as in Asia 1997 and as widely threatened in the US Sub-Prime episode. The overall structure of the "generic crisis" set out in Table 1 links closely to this approach.

Secondly, the relevance of the "uncertainty" approach ${ }^{5}$ has been shown by repeated problems with institutions' exposures to financial innovations, whose properties are not yet tested over a full cycle and are thus subject to uncertainty. The current bank exposures to Asset Backed

2 They may, however, lead to resource misallocation and an increased cost of capital, with deflationary macroeconomic implications.

3 It is not denied that all sharp asset price changes will tend to affect market liquidity to a greater or lesser degree

4 This suggests that financial crises follow a credit cycle with an initial positive shock (displacement) provoking rising debt, mispricing of risk by lenders and an asset bubble, which is punctured by a negative shock, leading to a banking crisis.

5 Under this approach, uncertainty as opposed to risk (in the sense of Knight 1921) is seen as a key feature of financial instability, in that unlike the cycle, one cannot apply probability analysis to rare and uncertain events such as financial crises and policy regime shifts and hence price risk of them correctly. Innovations are by definition subject to such uncertainty because probabilities are not yet known over the full cycle. 
Securities (ABS) entailing credit risk transfer is a case in point. Equally, the "disaster myopia" theory 6 is illustrated by the apparent short memories of instability once a period of calm has been observed. Disaster myopia highlights incentives leading to underpricing of risk and these may in turn reflect expectations of safety net provision and risk taking incentives under capital adequacy regulations, both of which have been seen in the Sub-Prime crisis.

\section{(d) Recent theoretical research findings}

Allen (2005) ${ }^{7}$ models links between asset price bubbles and financial fragility. Central to bubble creation are principal-agent conflicts since bank managers' upside-risk payoffs increase in risk whereas limited financial liability ensures restricted downside-risk losses ${ }^{8}$. With intermediation, investors place borrowed funds ${ }^{9}$ into risky assets such as commercial property and transfer default risk onto lenders. This motivates borrowers to bid-up asset prices above their fundamental ${ }^{10}$ values creating a bubble. Moreover, bubbles are propagated by investors' expectations of higher future credit availability and credit volatility, since this allows higher asset returns via risk transfer.

Theoretical and empirical models of contagion are extensively reviewed by De Bandt and Hartmann (2002). Freixas and Parigi (1998) and Freixas et al. (2000) focus on direct bank linkages and suggest borrowing arrangements between banks cause a domino effect if one bank is unable to meet its obligations, sometimes due to depositors withdrawing funds from a single bank in fear of deposit withdrawals from others ${ }^{11}$. Resulting externalities which explain "rational herding” are modelled by Chen (1999).

Empirical work has shown contagion to be a valid concept. Autocorrelations between bank failures indicates concentrations of failures i.e. contagion (De Bandt and Hartmann, 2002). Abnormal bank stock price behaviour alongside "bad news" of banks' performance (tested by event studies) also shows contagion as does depositors' behaviour in response to bad news. Calomiris and Mason (2000) identified abnormally high withdrawals during the Great Depression. Jayanti and Whyte (1996) find significant increases in UK and Canadian banks' Certificate of Deposit rates after the Continental Illinois failure (1984), indicating international contagion.

Aspachs et al (2007) suggest two components should define financial fragility: reduced bank profitability and increased default probability, the advantage being that it can be applied at a firm or aggregate level (Goodhart et al, 2006). The combination is used because neither component alone implies fragility; lower profitability could arise through recession and excessive risk taking could raise defaults without instability. Heterogeneous agents with a distribution of risk appetites are used to link fragility with welfare changes; Aspachs et al (2007) show an exogenous banking system shock increases aggregate defaults, decreases profits and reduces agents' welfare. These theoretical predictions are calibrated against UK data.

6 This suggests that competitive, incentive-based and psychological mechanisms in the presence of uncertainty lead financial institutions and regulators to underestimate the risk of financial instability, accepting concentrated risks at low capital ratios.

7 The underlying model which also incorporates contagion via overlapping claims in inter-bank markets is detailed in Allen and Gale (2000).

8 At worst the manager loses her job and possibly reputation. Allen (2005) suggests that if default is not penalised and if reputation risk is low, the manager improves her expected return by gambling depositors' funds.

${ }^{9}$ Repayable at the borrowing rate.

10 A fundamental asset price is simply its payoff discounted by the investor's opportunity cost of her own funds.

11 This is motivated by the "first come, first served" process of depositor reimbursement. 
Shin (2008) suggests that by holding assets which are claims against other borrowers and by holding claims against each other, financial institutions generate complex webs of risk exposures; relative asset and liability values, credit availability and asset prices become interdependent. Resulting externalities mean shocks to financial systems are amplified, causing spillovers onto many balance sheets ${ }^{12}$. The author models a system of interlocking balance sheets to solve for asset prices which depend on the creditworthiness of other institutions in the system. He shows this fixed point problem has a well defined solution; each claim can be uniquely priced in terms of parameters describing the underlying financial system (current prices of underlying assets, debt levels and structure, and the profile of balance sheet inter-linkages).

Recent research has also focused on regulators' incentives. Kocherlakota and Shim (2006) suggest the regulator's response to instability is conditioned on the ex-ante probability of asset price collapse; if this is high, remedial action is optimal, otherwise the regulator shows forbearance towards instability. Principal-agent and political motives explain why regulators show forbearance (instead of "prompt corrective action") towards instability ${ }^{13}$. Degennaro and Thompson (1996) suggest regulators who act as utility-maximising agents, view forbearance as an attractive gambling strategy where taxpayers bear the costs for losing the gamble as has occurred already to some extent in the sub-prime context.

Besides validating a number of the above, the subprime crisis has generated important additional insights into systemic risk. Adrian and Shin (2008) focus on contagion via market price changes in the context of mark to market, where financial institutions' active balance sheet management generates a positive relation of leverage and balance sheet size. Institutions desire expansion in an upturn, boosting liquidity, while a shock to asset prices led to a desired contraction, but for subprime this was stopped by obligations (e.g. backup lines) - so instead banks cut back on discretionary lending - namely to the interbank market.

Brunnermeier (2008) considers amplifying mechanisms of liquidity shocks, which are firstly borrowers balance sheet effects. leading to a loss spiral and margin spiral, second a lending channel effect, leading to hoarding of liquidity, third runs on institutions and markets and fourth network effects as suspect institutions such as Bear Stearns may be blacklisted.

\section{Progress with the macroprudential pillar - the development of macroprudential oversight}

\section{(a) Definition}

Owing to costs of crisis, it has been realised that there is an immense premium on timely warnings regarding systemic risks as an input to policy decisions as well as to strategies and market behaviour of financial institutions. Accordingly, in the last decade 'macroprudential surveillance' - defined as monitoring of conjunctural and structural trends in financial markets so as to give warning of the approach of financial instability - has become a core activity for many central banks. We summarise progress here while pointing out below whether such surveillance is insufficient to provide an alternative pillar.

\footnotetext{
12 Presence of externalities means shocks are amplified symmetrically; a positive shock generates positive externalities and bank balance sheets benefit from asset price booms.

13 Kane (1992) defines forbearance towards low banking capital as a situation where "Deposit-institution regulators engage in capital forbearance when they lower standards for minimum net worth at de-capitalised institutions”, (p359). Prompt Corrective Action necessitates immediate termination of critically undercapitalised banks via asset liquidation (Kocherlakota and Shim, 2006).
} 


\section{(b) Methods of surveillance}

Typically, central banks institute regular "Financial Stability Reviews" to assess the outlook for financial stability. Already by end-2005, 50 central banks had done so (Cihak 2006), often prompted by IMF/World Bank Financial Sector Assessment Programmes (FSAPs).

Data needs (Davis 1999) include macroeconomic and financial data for assessing conjunctural conditions, non-financial sector debt, leverage and asset prices for considering vulnerability of borrowers, and in the light of these, bank balance sheets and income and expenditure for considering robustness of banks. Risk measures derived from financial prices complement leverage and income indicators. Stress tests and forecasts of indicators and derived stability indicators such as defaults and bankruptcies, including risks to the central projection are needed to tell a full story.

Key lesson learnt in surveillance practice for these data include the importance of economy in the number of variables to tell a coherent story; and derivation of data needs from theory and experience. Furthermore, there is a need to use qualitative aspects - surveillance cannot be purely numerical and unlike inflation is not easily summarised in a single index. Changes in regulation and competition, and innovation are among key qualitative inputs. Equally, there is a need to develop benchmarks and norms for the economy and financial system to assess deviations, while remaining aware that these can change (e.g. during financial liberalisation). Cross border as well as domestic influences need to be taken into account, not least given the internationalisation of banking. Also new players such as hedge funds need to be incorporated when they become relevant.

There is a need for observation of overall patterns in the light of past occurrences of financial instability, both at home and abroad, developments in theory and the generic view set out in Table 1. Viewed in the light of that table, data can show either shocks (e.g. triggering boom or crisis) or propagation mechanisms (showing a boom is underway). But since shocks are random, the vulnerabilities are the main focus. Then there is a need for a judgmental approach in drawing conclusions, using again a conceptual framework derived from theory such as that of Table 1 (how vulnerable is the system - what shocks could take place?) Fell and Schinasi (2005) suggest the use of an implicit corridor of financial stability, akin to an exchange rate target, with judgements made as to whether the system is inside the corridor, approaching the edge, just outside or systematically outside, which will imply different policy recommendations.

As an example of a procedure, the ECB undertake a 7-point vulnerabilities exercise, first identifying vulnerabilities and imbalances, then translating them into potential risk scenarios, identifying triggers (shocks) for the scenarios, assessing the likelihood of scenarios arising, estimating the costs for the financial system, assessing robustness to such shocks and then ranking the risk. They note the need to include endogenous sources of risk (within institutions, markets and infrastructure) as well as exogenous risks from the macroeconomy. Fell and Schinasi (2005) give a check list of criteria for sound analysis including: Is the process systematic? Are the risks identified plausible? Are the risks identified systemically relevant? Can linkages and transmission (or contagion) channels be identified? Have risks and linkages been cross-checked? Has the identification of risks been time consistent?

\section{(c) Tools for macroprudential analysis}


“Distance to Default” (DtD) ${ }^{14}$ measures credit risk by expressing a firm's net worth as a proportion of asset price volatility ${ }^{15}$; the higher this ratio, the lower the likelihood of default. Any asset with a liquid secondary market ${ }^{16}$ can be used because assuming market efficiency, prices should incorporate markets' forward looking expectations of firm default (Chan-Lau, 2006). However, when applied to banking distress, DtD ignores the risk of regulators intervening well before default. Hence Chan-Lau and Sy (2007) suggest banking DtD measures should reflect regulatory capital requirements, in line with the Basel Committee.

For a given confidence interval and time span, Value at Risk (VAR), a market risk measure, indicates the maximum expected portfolio loss under normal market conditions (Benninga and Weiner, 1998). Basle sets a 99\% confidence interval and a 10 day horizon, based on at least 12 months historic data. ${ }^{17}$ Banks must hold at least three times this VAR amount in capital. Criticisms arise because means, variances and correlations of asset returns are based on assumed probability distributions. Also, quantifying actual portfolio positions requires detailed knowledge of all asset risks by banks.

Stress tests quantify portfolio movements for unlikely but feasible events (see BIS, 2000 and 2001 for more detail). Scenario tests simultaneously vary several risks in one direction, emulating historic events or hypothetical scenarios. Sensitivity tests shock individual risks symmetrically ${ }^{18}$. Limitations arise because probabilities of shocks materialising are not computed. Also, risk parameters are at times subjectively chosen by managers and impose high computational costs on institutions.

Bubble ${ }^{19}$ detection searches for bubble premiums, excess volatility and cointegration between dividends and prices (Brooks and Katsaris, 2003). In older models, bubble components exploded over time whereas recent, more realistic models allow prices to return to fundamentals via crashes (Raymond Feingold, 2001). This makes detection by cointegration harder due to bias and kurtosis (Evans, 1991); hence correction for these will improve bubble detection (Raymond Feingold, 2001).

Early Warning Systems (EWS) generate out-of-sample probabilities of crisis using historic data. Demirguc-Kunt and Detragiache (1997) developed a parametric EWS for banking crises using a multinomial logit model with macroeconomic, financial and structural variables as inputs. Logistic models are appropriate for explaining binary banking crisis observations in panel data. Davis and Karim (2008a) improved prediction by introducing more countries, crises $^{20}$ and dynamics in the macro variables; over $90 \%$ of in-sample crises were correctly identified.

Kaminsky and Reinhart (1999) developed a non-parametric signal extraction EWS which tracks individual time series for abnormal behaviour that has previously been associated with crises. If a variable subsequently behaves abnormally, a crisis probability can be computed. Davis and Karim (2008a) improve signal extraction for banking crisis prediction by creating composites of indicators weighted by their signalling quality.

\footnotetext{
14 For a practical guide on DtD, see Crosbie and Bohn (2002).

15 Standard deviation of the annual percentage change in asset value.

16 Credit default swaps, corporate or sovereign bonds.

17 Hence this market risk measure is backward looking.

18 E.g. parallel yield curve shifts.

19 See part 2, section (c).

20105 countries are covered by data spanning 1979-2003 which yields 72 or 102 systemic banking crises depending on the crisis definition used.
} 
Difficulties in identifying systemic crises compromise the EWS dependent variable. Also, predictive accuracy varies according to the cut-off threshold subjectively chosen by the policymaker. Nevertheless, logistic and signal extraction techniques provide a computationally easy way to predict banking crises using global and country-specific data respectively and are thus useful tools to complement macroprudential surveillance.

A recent development is the binary recursive tree technique, which can be used to answer the question "which non-linear variable interactions make an economy more vulnerable to crisis than others?” It can be argued that liquidity, credit and market risks are all potentially nonlinear (e.g. once a threshold level of credit risk is surpassed, a decline in GDP may have a heightened impact on the probability of a crisis). The estimator identifies the single most important discriminator between crisis and non-crisis episodes across the entire sample, thereby creating two nodes. These nodes are further split into sub-nodes based on the behaviour of splitter variables' non-linear interactions with previous splitter variables. This generates nodal crisis probabilities and the associated splitter threshold values. This is an innovative approach used mainly in medical research to date. The technique has been applied to systemic banking crises by Duttagupta and Cashin (2008) and Davis and Karim (2008b). The key indicators used in these studies include real interest rates, GDP growth, inflation and credit variables.

\section{(d) The limits of macroprudential oversight - an evaluation for the subprime crisis}

Davis and Karim (2008b) show that the US sub-prime crisis was only partly foreseen by the policy community; although all had important insights. In their headline sections, it is notable that none of the reports highlighted the conduits and special investment vehicles (SIVs) that were a key feature of the crisis. None foresaw the collapse of the interbank market or the overall magnitude of the effects from the sub-prime crisis alone. None considered possible links from financial instability to the real economy that are being seen now.

Davis and Karim argued that the BIS had the most forward looking analysis of events and possible policy responses, reflecting its longer term concern over the build-up of debt, risks in structured products and rising asset prices. Even they failed to see some of the consequences of the crisis, notably the seizing up of interbank markets.

They also saw limits in the use of macroprudential tools. Among global early warning systems for the US and UK the logit performed best but was still only marginally able to help predict the crisis (although the BRT model had a higher average crisis prediction score). These results to some extent show that the sub prime crisis had specific features that were not typical of the average banking crisis in both advanced and emerging economies. However, their contention was that rather than rejecting such models, the results how they should be better adapted for the specific features of advanced countries, that may also include aspects of securities market instability. That would be a step towards making them a useful supplement for macroprudential analysis. Equally, we maintain that a generic features checklist would also be useful complement for such analysis. Nevertheless, it is important to acknowledge the ongoing limitations of knowledge and ability to predict crises using macroprudential surveillance tools.

\section{$4 \quad$ Policy issues - making macroprudential regulation operational}

\section{(a) The broad issue}


The initial two policy objectives of macroprudential regulation are early identification of potential vulnerabilities; and through their public reporting, to encourage financial institutions to do stress testing. The more difficult policy decision is what to do if there are macroprudential warnings, given the third objective is to promote preventative and remedial policies to prevent financial instability. Surveillance should also help to resolve instabilities when preventative and remedial measures fail, but this is not the desirable scenario.

Moral suasion and intensified supervision are obvious preventative measures but may not be sufficient. Or equally, the question arises whether monetary policy can deal with asset price bubbles - many central bankers seem to oppose the idea that monetary policy should aim to deflate nascent bubbles, arguing that the interest rate is best devoted to control of inflation. Experience suggests there is a need for variation or adjustment in prudential parameters, which we explore in this section.

Bear in mind that the whole rationale of macroprudential regulation is that relying on individual bank supervision at a micro level is not sufficient. Clearly lower capital adequacy makes banks more vulnerable to failure, but equally the past decade has also shown the adverse incentive effects of capital adequacy, maximising risk in the buckets, for example and possibly banks skimping liquidity protection. The procyclicality of the financial system. which is already apparent with Basel I, seems set to worsen with Basel II (Goodhart 2005). Furthermore, in trying to make themselves safer, for example selling an asset when the price of risk rises, banks may collectively act in a way that generates systemic risk.

It is widely argued that the most desirable means of preventing financial crises is to implement standards which automatically act to prevent "financial fragility" from arising. This raises the issue is how to link macroprudential and microprudential regulation more effectively (Barrell and Davis, 2008). One aspect is the appropriate design of a countercyclical regulatory framework (the time series dimension). It also includes increasing risk weights for risks that are common across institutions rather than idiosyncratic (the cross section dimension). It is vital that regulation of both types becomes more effective in the sense of ensuring that risky activities do not migrate either internationally or to less-regulated financial institutions such as hedge funds (Goodhart 2008). The structure of regulation more broadly may need to be reconsidered.

\section{(b) Countercyclical regulation}

As noted, there is an on-going debate about whether Basel 2 has been made the financial system more or less pro-cyclical. Through-the-cycle ratings should tend to dampen the procyclical forces previously at work (Bank of England, 2008). The requirement for stress testing for a downturn under Pillar 2 should also act against pro-cyclicality by making banks consider the range of risks that can occur during a cycle or even a long period of time. However, the increased use of marking-to-market and banks' own assessment of risk may lead banks hit by falling credit quality to raise capital or contract balance sheets in downturns (since raising capital is difficult in such conditions) and thereby exacerbate the underlying weakness (Goodhart, 2005). Tougher liquidity standards introduced since the crisis will help to reduce pro-cyclicality, for example by reducing the ability for banks to expand balance sheets rapidly using wholesale funding.

There is limited international experience with designing regulatory standards that act against credit and asset-price cycles, for example by increasing minimum capital ratios to dampen lending growth, ensuring banks have buffers to draw on in the downturn. Dynamic provisioning is a rule requiring banks to build up loss reserves in good times to cope with 
losses in bad times and has been implemented in Spain. In the UK by contrast banks did not build up extra provisions in the upturn: the nonperforming loans/total loan ratio fell from $2.5 \%$ in 2003 to $1 \%$ in 2006, while the ratio of provisions to non-performing loans fell from $70 \%$ to $54.6 \%$. Potential conflicts with tax rules and with accounting standards would need to be addressed if this approach is to be implemented. The FSA (2009) is currently proposing a buildup of reserves over the cycle which might be part of regulatory capital or separate from it and would amount to $2-3 \%$ of risk weighted assets at the peak of the boom,

Moreover, a number of other national authorities are considering explicit countercyclical regulation (Bank of England, 2008). These could include an overall leverage ratio of capital to unadjusted (rather than risk-weighted) assets (FSA 2009). This limits the scope under Basel 2 arrangements for banks to assess their own risk by providing a one-size-fits-all ceiling and may be helpful in making regulation more transparent, although it is essential that ceiling applies to all relevant assets and does not encourage banks to use off-balance sheet structures to escape the ceiling. Time varying capital requirements related to lending growth are also under consideration, alongside the purchase of catastrophe capital insurance (Kashyap et al., 2008). Goodhart (2005) suggests linking the capital requirement on bank lending to the rate of change of asset prices, while another alternatives are to limit individual bank asset growth to a rate consistent with an inflation target. Brunnermeier et al (2009) wish to link capital adequacy to macroprudential factors reflecting maturity mismatch, credit expansion and asset prices, with a multiplicative effect that would be greater in a boom than during deleveraging.

In general, countercyclical policies based on discretion are likely to be difficult to implement as the authorities can easily share the same excessive optimism as the private sector about future prospects and risks (“disaster myopia”). In addition, authorities may face political pressures if they try to contain the expansionary phase of a credit cycle, particularly from the financial industry. A rules-based approach to pro-cyclicality, although blunter, would have the benefit of being transparent. It would be important that such an approach does not limit the important role of banks' risk management in ensuring the stability of the financial system.

Borio (2009) notes also that capital adequacy or even banking regulation generally are only one aspect of the procyclicality problem. Fair value accounting for example increased procyclicality in the sub-prime crisis. Monetary and fiscal policy as well as the nature of the safety net may also give rise to incentives. For example interest relief on real estate loans as in Sweden prior to the 1991 crisis. Hence there is a need for a holistic approach to the problem. Equally, generous deposit insurance was key background for the US Savings and Loans crisis.

\section{(c) Cross sectional regulation}

As mentioned, a second aspect of macroprudential regulation is to allow for cross sectional risks. A key aspect of this is that not all institutions give rise to similar systemic risks. These may be large and/or highly connected with other institutions. Brunnermeier et al (2009) wish to link capital adequacy to systemic status as well as asset growth by individual institutions. Developing models to measure such systemic importance is a key ongoing task, as in the Austrian model of interbank links (Elsinger et al 2006). Regulation may then need to impose closer regulation and possibly even higher capital requirements on systemically important institutions.

There may also higher capital charges on behaviour that is typically common across banks relative to that which is idiosyncratic, even if the risks to the individual institutions are the same. Areas in other words where banks are susceptible to "herding" behaviour and there is high correlation of balance sheet risk. So for example there could be tougher controls on 
lending to finance real estate, a major component of collective losses as asset prices fall. ${ }^{21}$ These could include limits to loan to value (LTV) ratios for property loans or restrictions on income gearing. Also there is a need to change bank reliance on wholesale funds, which have been seen to dry up simultaneously for all institutions. This could be by raising capital requirements for banks that have high wholesale funding ratios, or against the mismatch in maturity of assets and liabilities, adjusted for liquidity (e.g. a discount on assets acceptable as collateral by the central bank) (Brunnermeier et al 2009).

As argued in Barrell and Davis (2008), macroprudential problems are actually threefold - bad lending leading to losses giving rise to liquidity problems, excessive reliance on wholesale markets and complex instruments leading to confusion. Given the "uncertainty" problem with lack of experience of behaviour in downturns, there is a need for further regulation of complex instruments or an increase in capital held against them. For if they fail when tested, as have the majority of asset backed security innovations of the past decade, they can cause huge damage. Possibly this could be in the form of higher capital charges until a recession has taken place. Or more radically, there could be a need to justify innovations before they can be introduced, as is the case for drug testing.

\section{(d) Changes in the structure of regulation}

The boundary problem in regulation arises for all of the above issues. The basic point, as set out in Goodhart (2008) is to ensure that regulation which is effective does not merely lead to substitution flows towards the unregulated sector. He suggests a resolution could be to ensure that regulation only is effective occasionally, i.e. during the height of a credit/asset price driven boom. There is also a need for vigilance by regulators to ensure banks do not set up subsidiaries (e.g. SIVs) outside the regulatory net for which they are sufficiently reputationally connected to not allow them to fail.

Davis and Barrell (2008) argue that one key root cause of the crisis has been the decision in the 1980s and 1990s to move away from structural regulation (e.g. limits on competition, prices and scope of activities for financial institutions) to an almost sole concern with the efficiency of the financial system. Both should be of concern to regulators, and the costs and benefits of both should have been balanced. Efficient financial markets increase welfare, reduce risk premia and raise sustainable output. They also have a tendency to produce products that become widely adopted before they are stress tested in a recession, as discussed above, and also unsustainable levels of competition. Further prudential tightening and even some direct controls on bank activities may be needed.

Geographically, it can be argued that European wide financial markets need a single regulatory structure that ensures the solvency as well as the liquidity of all financial institutions in the European Economic Area. Macroprudential regulation raises important home/host issues since if there is most leverage for the home supervisor, the scope to take host country macroprudential issues into account will be limited. Arguably the macroprudential approach calls for host country supervision to have precedence.

In this context, a key issue is whether new institutions are needed, as proposed in the EU and US, to detect macroprudential risks? Some doubt is justified, in our view, since they may lack both credibility and leverage over the supervisors and central banks who will take the relevant decisions. Financial stability reports from such institutions may thus be disregarded even more readily than those produced by existing institutions.

${ }^{21}$ As shown in Davis (1993) real estate lending is both risky as an asset for banks per se and also losses on it are most highly correlated with aggregate losses by banks 
More appropriate may be close attention to the development of macroprudential regulation between the central bank and regulator (if they are separate) or within the central bank. It can be argued that regulators outside the central bank are often less focused on macroprudential issues than the central bank themselves. One reason may be greater focus on depositor and investor protection, which leads to a concentration on individual institutions. Another is that the central bank is more likely to have to deal with the initial consequences of systemic risk via the lender of last resort facility. Hence a rebalancing of responsibilities may be appropriate to ensure sufficient macroprudential focus.

In the UK for example, under the Banking Reform Act, the Bank of England has a legal objective "to contribute to protecting and enhancing the stability of the financial systems of the United Kingdom”. The Act formalises the Bank’s role in supervision of payments systems. A Financial Stability Committee is being set up within the Bank to deal with this objective, reporting to the Governor (HM Treasury, 2008). An important innovation under the Act is that the Bank is to be able to request data from banks through the FSA, whereas at present the FSA can only collect data it needs itself , Furthermore, these arrangements provide the basis for the Bank to have a much more detailed understanding of developments in the banking system (see also OECD 2009).

\section{(e) Further policy lessons}

Further, policy lessons over the last decade have been widespread. For example:

- The ongoing Japanese experience showed that resolution of a banking crisis is best undertaken rapidly, and as in the Savings and Loan crisis in the US, generous deposit insurance and forbearance can lead to worse problems.

- The Asian crisis illustrated the dangers of currency mismatch in corporate as well as bank balance sheets, as well as problems of weak corporate governance and the dangers of relying on the international interbank market for finance.

- The Russia/LTCM crisis, besides bringing market liquidity risk to the fore, showed that systemic risk can arise from unregulated hedge funds.

- The Argentine crisis showed how difficult renegotiation among bondholders can be for a defaulting country, as opposed to international banks as in 1982.

- The Sub-Prime crisis shows the possibility that the domestic interbank market can fail, and has necessitated innovations in lender of last resort policy, such as the Bank of England swapping government bonds for illiquid mortgage backed securities.

\section{Conclusion}

The past decade has seen an unprecedented focus on financial instability, its nature and its early detection. Whereas this is clear progress compared to the blind manner in which many countries encountered financial instability in the late 1980s, there is still a long way to go. This was illustrated by the failure of Financial Stability Reviews (e.g. of the UK, ECB and the IMF) to detect the liquidity aspect of the Sub-Prime crisis, even though they did give warnings of the credit risk issues arising. See Banque de France (2008) for an assessment of liquidity issues in the wake of the sub-prime crisis. Also, the crisis has shown a rich array of adverse incentive effects on risk taking, often arising from regulation. It is suggested that the role of incentives is an emerging issue which warrants close focus (Chai and Johnston (2000) gave an early approach to it). And even if vulnerability had been detected, experience has also shown that the means by which authorities can address macroprudential concerns are quite limited. Hence the need for a wider range of macroprudential tools and particularly those that will tend to limit ex ante the scope of systemic risk, in time series and cross sectional terms. 


\section{REFERENCES}

Adrian T and Shin H S (2008), "Liquidity and financial contagion”, in "Banque de France Financial Stability Review: Special Issue on Liquidity”, No. 11, 1-7.

Allen, F (2005). “Modelling Financial Instability”. National Institute Economic Review, No. 192, April 2005.

Allen, F and Gale, D (2000). “Bubbles and Crises”. Economic Journal, 110, pp236-55.

Aspachs, O, Goodhart, C A.E., Tsomocos, D P. and Zicchino, L (2007). "Towards a Measure of Financial Fragility". Annals of Finance, Springer, vol. 3, issue 1, pages 37-74.

Bank of England (2008), “Financial Stability Report, October 2008”, Bank of England, London.

Banque de France (2008), “Financial Stability Review, Special Issue on Liquidity”, BdF, Paris

Barrell, R. and E. P Davis (2008), “The Evolution of the Financial Market Crisis in 2008”, National Institute Economic Review, No. 206.

Benninga, S. and Weiner, Z. (1998). "Introduction to Value at Risk". Mathematica in Education and Research, Vol. 7, Issue 4, pp 39 - 45

Bernard H and Bisignano J (2000), "Information, liquidity and risk in the international interbank market: implicit guarantees and private credit market failure", BIS Working Paper No 86

BIS (2000). "Stress Testing by Large Financial Institutions: Current Practice and Aggregation Issues". Committee on the Global Financial System, Bank for International Settlements, Switzerland.

BIS (2001). "A Survey of Stress Tests and Current Practice at Major Financial Institutions". Report by a Task Force Established by the Committee on the Global Financial System of the Central Banks of the G10 Countries. BIS Publications, Bank for International Settlements, Switzerland.

Borio C (2009), "The macroprudential approach to regulation and supervision, What? How Why?” presentation to the Banque de France and Toulouse School of Economics Conference on "the future of financial regulation", 28 January 2009

Brooks, C and Katsaris, A (2003). "Rational Speculative Bubbles: An Empirical Investigation of the London Stock Exchange". Bulletin of Economic Research, Vol. 55, Issue 4, pp319-346.

Brunnermeier, M. (2009), “Deciphering the 2007/8 Liquidity and Credit crunch”, Journal of Economic Perspectives, No. 23.

Brunnermeier, M. Crockett A, Goodhart C, Persaud A D and Shin H (2009), "The fundamental principles of financial regulation”, Geneva Reports on the World Economy 11, International Center for Monetary and Banking Studies and Centre for Economic Policy Research

Calomiris, C W. and Mason, J R. (2000). "Causes of U.S. Bank Distress During the Depression".NBER Working Papers 7919, National Bureau of Economic Research, Inc.

Chai J and Johnston R B (2000), “An incentive approach to identifying financial system vulnerabilities”, IMF Working paper No WP/00/211

Chan-Lau, J A. and Sy, A N.R.(2007). "Distance-to-Default in Banking: A Bridge Too Far?". Journal of Banking Regulation, Vol. 9, No. 1, pp. 14-24, November 2007.

Chan-Lau, J. A. (2006) 'Market-Based Estimation of Default Probabilities and Its Application to Financial Surveillance', International Monetary Fund Working Paper 06/104, Washington, DC,

Chen, Y. (1999). "Banking Panics: The Role of the First-Come, First-Served Rule and Information Externalities”. Journal of Political Economy, Vol.107, Issue 5.

Cihak M (2006), “How do central banks write about financial stability?”, IMF Working Paper WP/06/163

Crosbie, P J. and Bohn, J, R. (2002). "Modelling Credit Risk". Published by KMV LLC, California, USA.

Das U, Quintyn M, Chenard K (2004), “Does regulatory governance matter for financial system stability?”, IMF Working Paper WP/04/89

Davis E P (1993), "Bank credit risk", Working Paper No. 8, Bank of England, London.

Davis E P (1994), "Market liquidity risk", in Eds. Fair D. and Raymond R., "The Competitiveness of Financial Institutions and Centres in Europe", Kluwer Academic Publishers 
Davis E P (1999), "Financial data needs for macroprudential surveillance: what are the key indicators of risk to domestic financial stability?” Lecture Series No 2, Centre for Central Banking Studies, Bank of England.

Davis, E P (1995), “Debt, financial fragility and systemic risk”, Oxford University Press

Davis, E. P and Karim D (2008b), “Could Early Warning Systems Have Helped to Predict the Sub-prime Crisis?”, National Institute Economic Review, No. 206.

Davis, E. P and Karim, D (2008a). “Comparing Early Warning Systems for Banking Crises”. Journal of Financial Stability,

Davis, E. P and Karim, D (2008c), “Research in and Policy for Financial Stability - What Have We Learnt?”, Economics and Finance Working Paper, No. 08-14, Brunel University

Davis, E.P (2002), ‘A typology of financial instability’, Financial Stability Report, 2, Oesterreichische Nationalbank, Vienna

De Bandt, O and Hartmann, P (2000). "Systemic Risk: A Survey". ECB Working Paper No. 35, European Central Bank.

Degennaro, R P. and Thomson, J B. (1996). “Capital Forbearance and Thrifts: Examining the Costs of Regulatory Gambling”. Journal of Financial Services Research, Volume 10, Issue 3, pp. 199-211.

Detragiache, E and Demirguc-Kunt, A (1997). "The Determinants of Banking Crises - Evidence from Developing and Developed Countries," IMF Working Papers 97/106, International Monetary Fund.

Duttagupta, R and Cashin, P (2008). “The Anatomy of Banking Crises”. IMF Working paper series , No. 08/93, Washington, IMF.

Elsinger, H., A. Lehar, and M. Summer (2006): "Risk Assessment for Banking Systems," Management Science, 52, 1301-1314.

Evans, G.(1991). "Pitfalls in Testing for Explosive Bubbles in Asset Prices". American Economic Review, September 1991.

Fell J and Schinasi G (2005), “Assessing financial stability - exploring the boundaries of analysis”, National Institute Economic Review, 192, 70-85

Freixas, X and Parigi, B (1998). “Contagion and Efficiency in Gross and Net Interbank Payment Systems”. Journal of Financial Intermediation, Vol. 7, Issue 1.

Freixas, X, Parigi, B. and Rochet, J-C (2000). "Systemic Risk, Interbank Relations and Liquidity Provision by the Central Bank”. Journal of Money, Credit and Banking, Vol. 32 Issue. 3/2.

FSA (2009), “The Turner Review, a regulatory response to the global banking crisis”, Financial Services Authority, London

Goodhart C A E (2005), “Financial regulation, credit risk and financial stability”, National Institute Economic Review, 192, 70-79

Goodhart C A E (2008), “The boundary problem in financial regulation”, National Institute Economic Review, 206, 48-55

Goodhart, C A E, Sunirand, P and Tsomocos, D (2006). "A Model to Analyse Financial Fragility". Economic Theory, Springer, vol. 27, Issue 1, pages 107-142.

HM Treasury (2008), “Financial Stability and Depositor Protection: Strengthening the Framework”, January 2008, HM Treasury, London.

Hoggarth G and Victoria S (2001), “Costs of banking system instability, some empirical evidence”, Financial Stability Review, Summer 2001, Bank of England

Jayanti, S. and Whyte, A. (1996). "Global Contagion Effects of the Continental Illinois Failure," Journal of International Financial Markets, Institutions and Money, 6(1),87-99.

Kaminsky L G and Reinhart C M. (1999), “The twin crises; the causes of banking and balance-of-payments problems”, American Economic Review, 89, 473-500

Kaminsky L.G. and Reinhart C.M. (1999). "The Twin Crises; the Causes of Banking and Balance of Payments Problems”. The American Economic Review, Vol. 89, No. 3, pp 473-500.

Kane, E (1992). “Corporate Capital and Government Guarantees”. Journal of Financial Services Research, Volume 5, Issue 4, pp. 357-368. 
Kashyap A, Rajan R and Stein J (2008), “Rethinking capital regulation”, paper presented at the Kansas Fed Symposium at Jackson Hole, Wyoming

Kindleberger C P. (1978), “Manias, Panics and Crashes, A History of Financial Crises”, Basic Books, New York.

Knight F H. (1921), "Risk, uncertainty and profit”, Boston; No. 16 in a series of rare texts in economics, republished by the LSE.

Kocherlakota, N and Shim, I, (2006). "Forbearance and Prompt Corrective Action". BIS Working Paper No. 177, Bank of International Settlements.

Mayes D and Pringle R (eds) (2009),“New Frontiers in the Regulation and Oversight of the Financial System”, Central Banking Publications, London

Minsky H P. (1977), “A Theory of Systemic Fragility” in Altman E I and Sametz A W ed, Financial Crises, Wiley, New York.

OECD (2009), “Economic survey of the UK, 2008”, Organisation for Economic Cooperation and Development, Paris.

Raymond Feingold, H (2001). "Preventing Crisis by Testing for Bubbles: A Comparative Study of the Financial Fragility of Europe Relative to the USA and Japan". EFMA 2001 Lugano Meetings, European Financial Management Association.

Shin, H S. (2008). “Risk and Liquidity in a System Context”. Journal of Financial Intermediation, 17, 315-329 